\title{
Public health approach of clinical trials: Cuban's experience of research translation into clinical practice
}

\author{
Maria A Pascual", Martha M Fors, Gladys Jiménez, Isabel López, Ania Torres \\ From Health Services Research: Evidence-based practice \\ London, UK. 1-3 July 2014
}

\section{Background}

Controlled Clinical Trials are the Gold Standard to assess the efficacy and safety of a new therapeutic intervention. Furthermore, their results are used to make decisions in relation to public health issues[1]. This study describes the experience of the National Centre of Clinical Trials (CENCEC) of Cuba[2] introducing research results into medical practice, extending new therapeutic technologies, identifying barriers to the translation of research into medical practice, improving the evidence for making decisions in public health and improving the delivery of medical services[3].

\section{Material and methods}

All trials led by CENCEC from 1992 to 2013 were characterized according to specific variables. A review of available information at the Cuban Regulatory Agency regarding the registration process of new drugs was performed. Interviews to sponsors, clinical investigators and health authorities were carried out to identify products registered outside the country, health benefits and impact of the results of clinical trials conducted by CENCEC.

\section{Results}

In this period, 133 clinical trials were completed evaluating 58 products from 28 sponsors, with participation of 1075 clinical sites from 90 hospitals and 60 primary care health care units involving 4241 researchers. Some of those studies were performed for the evaluation of health technologies and to search evidence for public health decisions. The activities of CENCEC were carried out according to international standards: Quality Assurance
System Certificated (ISO 9001:2008), Cuban Public Registry of Clinical Trials (WHO Primary registry [4] and role as regional coordinator of Good Clinical Practices Working Group (PANDRHA) among others.

The benefits of "new intervention" clinical trials were related to morbidity and mortality rates, new patterns of disease management, better Infrastructure of clinical sites, improvement of the quality of medical care, the introduction of new technologies and the building of capacity of clinical investigators [5].

\section{Conclusions}

The experience of Cuba, a low income country with a defined health policy, shows that the results of clinical trials are an effective tool to improve health services and for an efficient introduction of evidence in medical practice, for decision making in public health leading to improvements in clinical care. The experience gained could be applied in other countries of Latin America to achieve public health results .

Published: 7 July 2014

\section{References}

1. Victora CG, Habicht JP, Bryce J: Evidence-based public health: moving beyond randomized trials. Am J Public Health 2004, 94:400-5.

2. Pascual MA, et al: Cuba's National Clinical Trials Coordinating Center: Emergence, Evolution, and Main Results. MEDICC Review 2011, 13(1).

3. Oliver, et al: A systematic review of barriers to and facilitators of the use of evidence by policymakers. BMC Health Services Research 2014, 14:2 [http://www.biomedcentral.com/1472-6963/14/2].

4. Jiménez G, Pascual M, et al: The Cuban Public Registry of Clinical Trials: primary registry of World Health Organization. Journal of Evidence-Based Medicine 2011, 4(3):161-164.

5. Milat AJ, et al: Increasing the scale and adoption of population health interventions: experiences and perspectives of policy makers, practitioners, and researchers. Health Research Policy and Systems 2014, 
12:18[http://www.health-policy-systems.com/content/12/1/18], doi:10.1186/ $1478-4505-12-18$

doi:10.1186/1472-6963-14-S2-P149

Cite this article as: Pascual et al:: Public health approach of clinical trials:

Cuban's experience of research translation into clinical practice. BMC

Health Services Research 2014 14(Suppl 2):P149.

Submit your next manuscript to BioMed Central and take full advantage of:

- Convenient online submission

- Thorough peer review

- No space constraints or color figure charges

- Immediate publication on acceptance

- Inclusion in PubMed, CAS, Scopus and Google Scholar

- Research which is freely available for redistribution

Submit your manuscript at 